\title{
INHERITANCE OF GRAIN YIELD AND ITS CORRELATION WITH YIELD COMPONENTS IN BREAD WHEAT (Triticum aestivum L.)
}

\author{
Jinbao YAO*, Xueming YANG, Miaoping ZHOU, Dan YANG, Hongxiang MA
}

\author{
Provincial Key Laboratory of Agrobiology, Jiangsu Academy of Agricultural Sciences, Nanjing, CHINA \\ *Corresponding author: yaojb@jaas.ac.cn
}

Received: 10.12.2013

\begin{abstract}
The inheritance of grain yield plant ${ }^{-1}$ and its correlation with other yield components were investigated in a diallel cross of seven wheat parents during the crop season of 2011-2012. Mean square of GCA effect was 2.90 for grain yield plant-1, which was highly significant $(P<0.01)$, indicating that additive effect played important role in the inheritance of the trait. SCA effect was also highly significant $(P<0.01)$ for grain yield plant-1 (0.68), suggesting that the trait was also controlled by non-additive effect. The estimates of GCA showed that the best combiner for grain yield plant-1 was Ningmai 9. The additive-dominance model was partially adequate for grain yield plant-1 and it was controlled by the over dominance type of gene action. Ningmai 8 possessed maximum dominant genes, whereas Yangmai 9 had maximum recessive genes. Grain yield plant-1 might be controlled by two groups of genes and exhibited moderately high value of narrow sense heritability $(\mathrm{h} 2 \mathrm{~N}=69.51 \%)$. The statistical analysis revealed that grain yield plant-1 was positively and significantly correlated with tillers plant $1(\mathrm{rp}=0.584, \mathrm{rg}=0.595)$ and number of grains spike-1 $(\mathrm{rp}=0.528, \mathrm{rg}=0.507)$ at phenotypic and genotypic levels.
\end{abstract}

Key words: diallel cross, grain yield, inheritance, Triticum aestivum $L$.

\section{INTRODUCTION}

Wheat (Triticum aestivum L.) is an important cereal crop next to rice in both acreage and production constituting about $22 \%$ of the staple food in China ( $\mathrm{Lu}$ et al., 2010) . Wheat has been cultivated in an area of 24.2 million hectares with the total production of 115 million metric tons in the year of 2010-2011 (Shen, 2012). The average yield of wheat in China is $4.75 \mathrm{t}$ ha- 1 , which is low as compared to other leading wheat producers in the world like Germany and France where average yields are $7.4 \mathrm{t}$ and $7.2 \mathrm{t} / \mathrm{ha}$, respectively. The yield is generally insufficient to fulfill the domestic requirements due to the increase in population (Xiao, 2006). Therefore, it is necessary to develop the new wheat cultivars, having wider genetic base capable of producing better yield under a wide range of agro-climatic conditions.

The grain yield of wheat is determined by three yield components: productive spikes per unit area, number of grains spike-1 and 1000-grain weight (Tian et al., 2012). The grain yield and its components are controlled by many genes, whose expression is greatly influenced by the varying environments (Groos et al., 2003). In most of the diallel studies of wheat, grain yield plant-1 seemed to be controlled by over dominance type of gene action (Singh and Sharma, 1976; Hussain et al., 2008; Akram et al., 2009; Ojaghi and Akhundova, 2010; Ahmad et al., 2011). However, researchers like Riaz and Chowdhry (2003);
Samiullah et al. (2010) and Farooq et al. (2010) observed partial dominance with additive type of gene action for grain yield plant-1. Zhang and Xu (1997) reported that grain yield plant-1 could result from additive and dominant genes with the possibility of epistatic genetic effects. Heritability estimate is a valuable parameter for determining the magnitude of genetic gain from selection. Low, medium, and high narrow sense heritability estimates were reported for grain yield plant-1 (Mckendry et al., 1998; Novoselovic et al., 2004; Liu and Wei, 2006; Erkul et al., 2010; Ahmad et al., 2011). Grain yield in wheat is a complex trait including number of fertile tillers plant-1, number of grains spike-1 and 1000-grain weight, and it is closely associated with its components (Khaliq et al., 2004; Munir et al., 2007; Ali et al., 2008).

The objective of this study was to investigate combining ability, and gene action for grain yield plant-1, and its correlations with yield components in a population of the $7 \times 7$ incomplete diallel cross experiment in wheat. The result of this study can be used in the selection of desirable parents for an effective breeding program to develop the new wheat varieties with high yield potential.

\section{MATERIALS AND METHODS}

\section{Plant materials}

The experimental material comprised of seven wheat varieties: Ningmai 8, Ningmai 9, Yangmai 158, Yangmai 
9, Jimai 17, Zheng 9023, and Yumai 18. The parents were chosen based on their broad genetic background and large variations for grain yield plant-1 and yield components (Table 1). These genotypes were crossed in an incomplete diallel fashion during April, 2011. For each of the cross, 15 spikes were emasculated and bagged to avoid contamination with foreign pollen. Pollination with the pollen collected from the specific male parent was done in the morning when the ovaries became receptive. At maturity the seeds from each cross were harvested and stored separately.

Table 1. Genetic background and yield traits of the seven parents

\begin{tabular}{llccccc}
\hline \multicolumn{1}{c}{ Parents } & \multicolumn{1}{c}{ Pedigree } & $\begin{array}{c}\text { Released } \\
\text { year }\end{array}$ & $\begin{array}{c}\text { Grain yield } \\
\text { plant }^{-1} \text { (g) }\end{array}$ & $\begin{array}{c}\text { Tillers } \\
\text { plant }^{-1}\end{array}$ & $\begin{array}{c}\text { No. grains } \\
\text { spike }^{-1}\end{array}$ & $\begin{array}{c}\text { 1000-grain } \\
\text { weight(g) }\end{array}$ \\
\hline Ningmai 8 & Yangmai 5/Yang 86-17 & 1996 & 7.43 & 4.53 & 51.17 & 32.51 \\
Ningmai 9 & Yang 86-17/Xifeng & 1997 & 9.03 & 4.97 & 55.52 & 32.86 \\
Yangmai 158 & Yangmai 4/st1472-506 & 1993 & 9.39 & 4.80 & 48.96 & 39.75 \\
Yangmai 9 & Jian 3/Yangmai 5 & 1996 & 7.80 & 4.77 & 47.98 & 34.12 \\
Jimai 17 & Lingfen 5064/Lumai 13 & 1999 & 7.12 & 5.13 & 39.40 & 35.70 \\
Zheng 9023 & [83(2)3-3/84(14)43//Xiaoyan & 2001 & 8.05 & 4.93 & 37.81 & 43.45 \\
Yumai 18 & 6/Xinong 65]F/3/Shannong 13 & 1990 & 7.17 & 4.93 & 42.43 & 34.72 \\
\hline
\end{tabular}

\section{Experimental design}

The seeds of 7 parents and $21 \mathrm{~F} 1$ hybrids were sown in the experimental field, Jiangsu Academy of Agricultural Sciences, Nanjing, China, in the first week of November in 2011 and in a Randomized Complete Block Design with three replications. Plant-to-plant and row-to-row spacing was 6.5 and $25 \mathrm{~cm}$, respectively. Within each block, each genotype occupied a plot of two rows of $2 \mathrm{~m}$ long. Standard cultural operations including weeding, fertilizers and disease control were carried out uniformly. At maturity, in late May 2012, ten plants were randomly selected from each of the parents and F1 progenies to determine fertile tillers plant-1, number of grains spike-1, 1000 -grain weight and grain yield plant-1.

\section{Statistical analysis}

To assess the differences among parents and F1 progenies, the data were subjected to analysis of variance using the SAS software (SAS Institute Inc. $2002 \&$ 2003). The general and specific combining ability values were estimated using Method II, Model I of Griffing's (1956). Two scaling tests (Mather and Jinks, 1982) were applied to test the validity of the additive-dominance model. Further, the Hayman (1954) method was used for estimation of gene actions. Correlation coefficients between grain yield plant-1 and yield components were determined using the data processing system (Tang and Feng, 2002).

\section{RESULTS AND DISCUSSION}

\section{Analysis of variance}

Analysis of variance revealed highly significant differences $(\mathrm{P} \leq 0.01)$ among the genotypes for grain yield plant-1 (Table 2). These results permitted further analysis of combining abilities. Both general combining ability (GCA) and specific combining ability (SCA) variances were highly significant for grain yield plant-1 (Table 2), indicating the importance of both additive and nonadditive gene effects. These results were in agreement with earlier findings (Wang et al., 2003; Farooq et al.,
2006; Hussain et al., 2012). However, Akram et al. (2011) illustrated that the additive effects were more important for the genetic control of grain yield plant- 1 .

Table 2. Analysis of variance for combining ability for grain yield plant $^{-1}$

\begin{tabular}{lllll}
\hline Source of variation & df & SS & MS & F \\
\hline Replications & 2 & 7.329 & 3.664 & $4.339^{*}$ \\
Genotypes & 27 & 95.131 & 3.523 & $4.172^{* *}$ \\
Error & 54 & 45.609 & 0.845 & \\
\hline GCA & 6 & 17.424 & 2.904 & $10.315^{* *}$ \\
SCA & 21 & 14.287 & 0.680 & $2.416^{* *}$ \\
Error & 54 & 15.203 & 0.282 & \\
\hline *, ** Significance at $\mathrm{P} \leq 0.05$ and $\mathrm{P} \leq 0.01$ levels, respectively
\end{tabular}

\section{Performance of parents and combining ability}

Mean grain yield plant-1 and GCA effects of parents were given in Table 3. Significant differences were found for grain yield plant-1 among parents. Yangmai 158 and Ningmai 9 had significantly higher grain yield plant-1 than other five parents and they can be considered as high yielding parents. Zheng 9023 had moderately high yield capacity while Ningmai 8, Yangmai 9, Jimai 17 and Yumai 18 had medium and low yield capacity. Estimates of GCA effects of parents ranged from $\square 0.625$ to 0.915 (Table 3). The highest positive-valued GCA was exhibited for Ningmai 9 followed by Yangmai 158. The GCA value of Ningmai 9 was significantly higher than that of Zheng 9023, Yangmai 9, Jimai 17, Yumai 18 and Ningmai 8 except Yangmai 158. This result indicated that Ningmai 9 was the best combiner for grain yield plant- 1 and may serve as genetic sources in breeding programs to increase grain yield. The highest negative-valued GCA was found for Ningmai 8 followed by Yumai 18. The positive and significant correlation $(\mathrm{r}=0.900, \mathrm{P} \leq 0.01)$ between GCA and parental performance (Table 3) suggested that selection of parents for grain yield plant- 1 could be made on the basis of their performance per se. The high grain yield plant- 1 of certain crosses (Ningmai $8 \times$ Jimai 17 , Ningmai $9 \times$ Zheng 9023, and Ningmai $9 \times$ Yangmai9) 
showed strong positive SCA effects (Table 4). Because in most cases at least one good combining parent was included in these crosses, their progenies had higher grain yield plant-1 than the overall means and yielded desirable transgressive segregations.

Table 3. Mean grain yield plant ${ }^{-1}$ and general combining ability (GCA) effects

\begin{tabular}{lll}
\hline Parents & GCA & Mean $(\mathbf{g})$ \\
\hline Ningmai 9 & $0.915 \mathrm{aA}$ & $9.031 \mathrm{aA}$ \\
Yangmai 158 & $0.480 \mathrm{abAB}$ & $9.387 \mathrm{aA}$ \\
Zheng 9023 & $0.143 \mathrm{bcBC}$ & $8.045 \mathrm{bcABC}$ \\
Yangmai 9 & $0.006 \mathrm{bcBCD}$ & $7.799 \mathrm{cBC}$ \\
Jimai 17 & $-0.325 \mathrm{cdCD}$ & $7.123 \mathrm{cC}$ \\
Yumai 18 & $-0.594 \mathrm{dD}$ & $7.169 \mathrm{cC}$ \\
Ningmai 8 & $-0.625 \mathrm{dD}$ & $7.434 \mathrm{cC}$ \\
r (GCA, mean) & $0.900^{* *}$ &
\end{tabular}

The values followed by different capital or small letters within the same column are significantly different at the 0.01 and 0.05 probability levels, respectively. ${ }^{* *}$ Significance at $\mathrm{P} \leq 0.01$ level. $\mathrm{r}$ correlation coefficient

\section{Assessment of grain yield plant-1 for Additive-Dominance model}

The data were assessed for Additive-Dominance (AD) model by exploiting various adequacy parameters given in
Table 5. According to Mather and Jinks (1982) the data will only be valid for genetic interpretation if the value of regression coefficient (b) must deviate significantly from zero but not from the unity. The regression analysis revealed that regression coefficient for grain yield plant-1 departed significantly from zero but not from unity, suggesting the absence of non-allelic interactions in genetic behavior of grain yield plant-1 which in turn attested the data valid for $\mathrm{AD}$ model for the trait. The appropriateness of the model data analysis was also verified by the analysis of variance of $(\mathrm{Wr}+\mathrm{Vr})$ and $(\mathrm{Wr}$ - Vr). The lack of significant variation in the $(\mathrm{Wr}-\mathrm{Vr})$ arrays suggested that any kind of epistasis was not involved in the phenotypic expression of the trait. Although the value of regression coefficient (b) proved the fitness of the data of grain yield plant-1 for AD model, mean square value of $(\mathrm{Wr}+\mathrm{Vr})$ for the trait indicated no significant deviation, thus emphasizing partial validity of the trait. This was also confirmed by Ahmad et al. (2011); Farooq et al. (2011) and Nazeer et al. (2011). The partially adequate model for grain yield plant-1 may be due to the presence of non-allelic interaction, linkage and nonindependent distribution of the genes in the parents as suggested by Mather and Jinks (1982).

Table 4. Effects of specific combining ability for grain yield plant ${ }^{-1}$ in 21 crosses

\begin{tabular}{lllllll}
\hline Parents & Ningmai 9 & Yangmai 158 & Yangmai 9 & Jimai 17 & Zheng 9023 & Yumai 18 \\
\hline Ningmai 8 & -0.267 & -0.843 & -0.439 & 1.377 & 0.274 & 0.052 \\
Ningmai 9 & & 0.641 & 0.999 & -0.152 & 1.023 & 0.877 \\
Yangmai 158 & & 0.701 & 0.664 & -0.693 & 0.196 \\
Yangmai 9 & & & 0.132 & 0.733 & -0.176 \\
Jimai 17 & & & & 0.381 & -0.424 \\
Zheng 9023 & & & & & & 0.287 \\
\hline
\end{tabular}

S.E. $\left(\hat{S}_{i j}-\hat{S}_{i k}\right)$ : Standard error of differences for SCA effect among crosses with a communal parent; S.E. $\left(\hat{S}_{i j}-\hat{S}_{k l}\right)$ : Standard error of differences for SCA effect among crosses without a communal parent. S.E. $\left(\hat{S}_{i j}-\hat{S}_{i k}\right)=0.708, L S D_{0.05}=1.415, L S D_{0.01}=1.882 ; S . E .\left(\hat{S}_{i j}-\hat{S}_{k l}\right)=0.662, L S D_{0.05}=1.324, L S D_{0.01}$ $=1.760$

Table 5. Adequacy test of additive-dominance model for grain yield plant ${ }^{-1}$

\begin{tabular}{ll}
\hline Parameters & \multicolumn{1}{c}{ Grain yield plant $^{-1}$} \\
\hline Joint regression (b) & $0.963 \pm 0.253$ \\
Test for $b=0$ & $3.806^{* *}$ \\
Test for $b=1$ & $0.146^{\mathrm{NS}}$ \\
Mean squares of $\mathrm{Wr}+\mathrm{Vr}$ between arrays & $1.334^{\mathrm{NS}}$ \\
Mean squares of $\mathrm{Wr}-\mathrm{Vr}$ between arrays & $0.230^{\mathrm{NS}}$ \\
Fitness of the data to Additive-Dominance model & Partial \\
\hline
\end{tabular}

** Significance at $\mathrm{P} \leq 0.01$ level, $\mathrm{NS}=$ non significant

\section{Genetic components of variation for grain yield plant-1}

Genetics of grain yield plant-1 was evaluated by calculation of the genetic components of variation $\mathrm{D}, \mathrm{H} 1$, $\mathrm{H} 2$ and $\mathrm{F}$ (Table 6). Additive (D) and non-additive (H1 and H2) components were significant, indicating that both additive and dominance effects were important components of genetic variation for grain yield plant-1. However, dominance ( $\mathrm{H} 1$ and $\mathrm{H} 2$ ) effects were greater than additive (D), suggesting that non-additive gene action played a predominant role in controlling the genetic mechanism of the trait. The (H1/D)0.5 was more than unity which confirmed the greater contribution of nonadditive genes in the inheritance of grain yield plant-1. These results were in accordance with those of Arshad and Chowdhry (2003); Hussain et al. (2008); Akram et al. (2009); Nazeer et al. (2010); Ojaghi and Akhundova (2010). Preponderance of dominance effects for grain yield plant-1 suggested that the selection for the trait in early generations may not be useful and it had to be delayed till late segregating generations. Asymmetrical distribution of dominant genes was confirmed by unequal 
estimates of $\mathrm{H} 1$ and $\mathrm{H} 2$, which was further supported by the value of $\mathrm{H} 2 / 4 \mathrm{H} 1$ (0.219). The $\mathrm{F}$ value, which estimates the relative frequency of dominant to recessive alleles in the parents, was negative. This suggests the excess of recessive alleles present in the parents, which was further supported by the small value $(<1.0)$ of [(4DH1)0.5+F]/ (4DH1)0.5-F]. The mean dominance effect of the heterozygote locus (h2) was significant, suggesting that heterosis breeding could be rewarding for this trait. Significant environmental component (E) indicated that the trait was highly affected by environmental conditions (Ahmad et al., 2011). The number of gene groups differentiating the parents $(\mathrm{k})$ was 1.984, suggesting the inheritance of grain yield plant-1 was controlled approximately by two groups of genes (Dere and Yildirim, 2006; Nazeer et al., 2010). Estimates of narrow sense heritability $(\mathrm{h} 2 \mathrm{~N})$ showed moderately high for grain yield plant-1. Such moderately high heritable value for grain yield plant-1 was also reported by other researchers (Novoselovic et al., 2004; Yang and Cao, 2005; Ajmal et al., 2009; Akram et al., 2009; Farooq et al., 2010). However Mckendry et al. (1998); Liu and Wei (2006); Erkul et al. (2010); Ojaghi and Akhundova (2010) found that the narrow sense heritability for grain yield plant-1 was low. Differences in the genetic material and analytical technique used in this study could account for these differences.

Table 6. Estimate of genetic parameters of grain yield plant ${ }^{-1}$ in a $7 \times 7$ diallel cross of wheat

\begin{tabular}{ll}
\hline Genetic parameters & Grain yield plant $^{-1}$ \\
\hline $\mathrm{D}$ & $0.487^{* *} \pm 0.118$ \\
$\mathrm{~F}$ & $-0.742^{* *} \pm 0.282$ \\
$\mathrm{H}_{1}$ & $1.663^{* *} \pm 0.283$ \\
$\mathrm{H}_{2}$ & $1.455^{* *} \pm 0.250$ \\
$\mathrm{~h}^{2}$ & $2.886^{* *} \pm 0.168$ \\
$\mathrm{E}$ & $0.315^{* * *} \pm 0.042$ \\
$\left(\mathrm{H}_{1} / \mathrm{D}\right)^{1 / 2}$ & 1.848 \\
$\mathrm{H}_{2} / 4 \mathrm{H}_{1}$ & 0.219 \\
{$[(4 \mathrm{DH}$} & )$^{1 / 2}+\mathrm{F} /\left(\left(4 \mathrm{DH}_{1}\right)^{1 / 2}-\mathrm{F}\right)$ \\
$\mathrm{K}$ & 0.416 \\
$\mathrm{~h}^{2}{ }_{\mathrm{N}}(\%)$ & 1.984 \\
$\mathrm{r}[(\mathrm{Wr}+\mathrm{Vr}), \mathrm{Pr}]$ & 69.51 \\
\hline$* *$ Significance at $\mathrm{P} \leq 0.01$ level. $\mathrm{r}$ correlation coefficient
\end{tabular}

\section{Graphical $(\mathrm{Vr} / \mathrm{Wr})$ representation for grain yield plant-1}

The $\mathrm{Vr} / \mathrm{Wr}$ graph (Fig. 1) showed that the regression line intercepted the Wr-axis below the point of origin, suggesting that the trait was controlled by the over dominance type of gene actions and this was superbly maintained by the results provided by the higher values of dominance components $\mathrm{H} 1$ and $\mathrm{H} 2$ over the additive one D. Similar results have earlier been reported by Asif et al., (1999); Chowdhry et al., (2002); Arshad and Chowdhry, (2003); Kashif and Khaliq, (2003); Saleem et al., (2005). However, these results were not in accordance with Riaz and Chowdhry (2003); Samiullah et al. (2010). The distribution of array points along the regression line (Fig. 1) revealed that parent Ningmai 8 contained maximum dominant genes being closest to the origin while parent
Yangmai 9 carried maximum recessive genes being farthest from the origin. The other two parents Jimai 17 and Yumai 18 also had relatively high frequency of recessive genes. Negative $r$-value $(r=-0.171)$ between parental values $(\mathrm{Pr})$ with $(\mathrm{Wr}+\mathrm{Vr})$ indicated that the parents with high grain yield plant-1 may carry dominant genes. Similar results were reported by Inamullah et al. (2006); Ojaghi and Akhundova (2010) while Dere and Yildirim (2006) reported that the parents with high grain yield plant-1 may carry recessive genes.

\section{Correlation analysis}

Correlation coefficients between grain yield plant-1 and yield components were shown in Table 7. In general, correlation coefficients at genotypic level were higher than those of phenotypic level. It might be due to depressing effect of environment on character association as reported earlier for wheat crop (Proda and Joshi, 1970). Grain yield plant-1 had a highly significant positive genotypic correlation with tillers plant-1 $(\mathrm{r}=0.595$, $\mathrm{P} \leq 0.01)$ and number of grains spike- $1(\mathrm{r}=0.507, \mathrm{P} \leq 0.01)$, and it showed positive and non-significant correlation with 1000-grain weight at both genotypic and phenotypic levels, suggesting that increase in tillers plant-1 and number of grains spike-1 would increase grain yield plant1. These results were in agreement with those of Ali et al. (2008). Khaliq et al. (2004); Munir et al. (2007) reported positive and significant genotypic and phenotypic correlation of grain yield plant-1 with yield components.

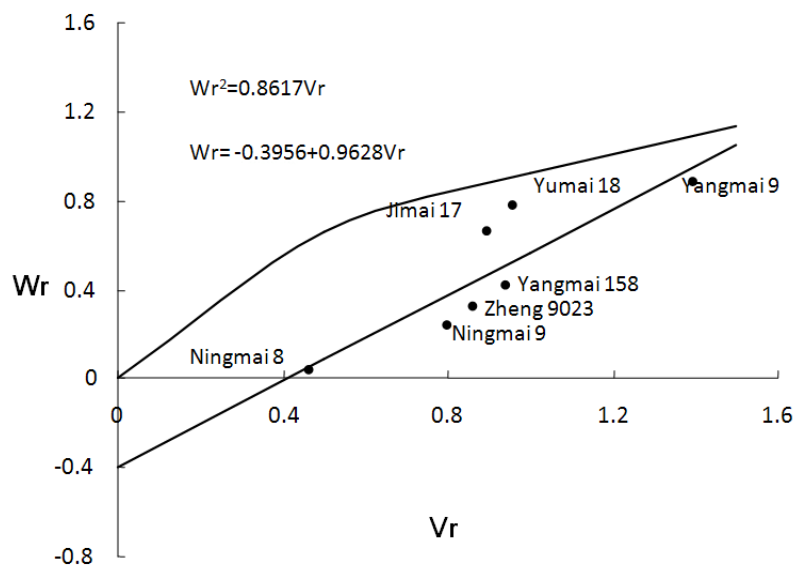

Fig 1. Vr versus Wr graph for grain yield plant ${ }^{-1}$

Among the yield components, Tillers plant-1 was positive and non-significant correlation with number of grains per spike and 1000-grain weight at genotypic level. Positive and non-significant correlation between tillers plant- 1 and number of grains spike-1 at both genotypic and phenotypic levels was also reported by Khan and Dar (2010). Positive and non-significant correlation between tillers plant-1 and 1000-grain weight was found at genotypic level, however the correlation was highly significant (Khokhar et al. 2010), whereas Kashif and Khaliq (2004) reported negative and significant association of tillers plant-1 with 1000-grain weight. There was negative and significant correlation between 
number of grains spike-1 and 1000-grain weight at both genotypic and phenotypic levels. Similar findings have also been reported by Khan et al. (2010). However, the results were contrary with the findings of Ashfaq et al. (2003).

\section{CONCLUSION}

The results revealed that there was significant genetic variation for grain yield plant-1 among the genotypes. Significant GCA and SCA effects for grain yield plant-1 implied the role of both additive and non-additive gene

Table 7. Phenotypic $\left(r_{p}\right)$ and genotypic $\left(r_{g}\right)$ correlation coefficient between grain yield plant ${ }^{-1}$ and yield components

\begin{tabular}{lllll}
\hline \multicolumn{1}{c}{ Characters $^{-1}$} & r & Tillers plant $^{-1}$ & Number of grains spike $^{-1}$ & 1000-grain weight \\
\hline grain yield plant $^{-1}$ & $r_{p}$ & $0.584^{* * *}$ & $0.528^{* * *}$ & 0.251 \\
& $r_{g}$ & $0.595^{* *}$ & $0.507^{* *}$ & 0.261 \\
Tillers plant $^{-1}$ & $r_{p}$ & & 0.107 & -0.062 \\
& $r_{g}$ & & 0.132 & 0.002 \\
Number of grains $_{\text {spike }^{-1}}$ & $r_{p}$ & & & $-0.552^{* *}$ \\
\hline
\end{tabular}

\section{ACKNOWLEDGMENTS}

This work was partially supported by the research projects (BY2012208, CX122026) funded by the Department of Science and Technology, Jiangsu, and Public Finance Office, Jiangsu, respectively.

\section{LITERATURE CITED}

Ahmad, F., S.Khan, S.Q.Ahmad, H.Khan, A.Khan and F.Muhammad. 2011. Genetic analysis of some quantitative traits in bread wheat across environments. Afr. J. Agric. Res. 6:686-692.

Ajmal, S.U., N.Zakir and M.Y.Mujahid. 2009. Estimation of genetic parameters and character association in wheat. J. Agric. Biol. Sci. 1:15-18.

Akram, Z., S.U.Ajmal, G.Shabbir, M. Munir and M.Cheema. 2009. Inheritance mechanism of some yield components in bread wheat. Pak. J. Agric. Res. 22:1-8.

Akram, Z., S.U.Ajmal, K.S.Khan, R.Qureshi and M.Zubair. 2011. Combining ability estimates of some yield and quality related traits in spring wheat (Triticum aestivum L.). Pak. J. Bot. 43:221-231.

Ali, Y., B.M.Atta, J.Akhter, P.Monneveux and Z.Lateef. 2008. Genetic variability, association and diversity studies in wheat (Triticum aestivum L.) germplasm. Pak. J. Bot. 40: 20872097.

Arshad, M. and M.A.Chowdhry. 2003. Genetic behaviour of wheat under irrigated and drought stress environment. Asian J. Plant Sci. 2:58-64.

Ashfaq, M., A.S.Khan and Z.Ali. 2003. Association of morphological traits with grain yield in wheat (Triticum aestivum L.). Int. J. Agri. Biol. 5:262-264.

Asif, M., I.Khaliq, M.A.Chowdhry and A.Salam. 1999. Genetic mechanism for some spike characteristics and grain yield in bread wheat. Pak. J. Boil. Sci. 2:948-951.

Chowdhry, M.A., A.Ambreen and I.Khaliq. 2002. Genetic control of some polygenic traits in Aestivum species. Asian J. Plant Sci. 1: 235-237.

Dere, S. and M.B.Yildirim. 2006. Inheritance of grain yield per plant, flag leaf width, and length in an $8 \times 8$ diallel cross population of bread wheat (T. aestivum L.) Turk. J. Agric. For. 30:339-345. actions in the genetic control of the trait. Ningmai 9 appeared to be a promising parent for improvement of grain yield plant- 1 . The additive-dominance model was partially adequate for grain yield plant-1. Dominant genes coupled with moderately high narrow sense heritability were involved in the inheritance of grain yield plant-1, suggesting that selection for the trait in early generations (F2 and F3) may not be effective. Grain yield plant-1 had significantly positive genotypic correlation with tillers plant- 1 and number of grains spike- 1 .
Erkul, A., A.Unay and C.Konak. 2010. Inheritance of yield and yield components in bread wheat (Triticum aestivum L.) cross. Turk. J. Field Crops 15:137-140.

Farooq, J., I.Habib, A.Saeed, N.N.Nawab, I.Khaliq and G.Abbas. 2006. Combining ability for yield and its components in bread wheat (Triticum aestivum L.). J. Agri. Soc. Sci. 2:207-211.

Farooq, J., I.Khaliq, M.A.Ali, M.Kashif, A.Rehman, M.Naveed, Q.Ali, W.Nazeer and A.Farooq. 2011. Inheritance pattern of yield attributes in spring wheat at grain filling stage under different temperature regimes. Aust. J. Crop Sci. 5:17451753.

Farooq, J., I.Khaliq, A.S.Khan and M.A.Pervez. 2010. Studing the genetic mechanism of some yield contributing traits in wheat (Triticum aestivum). Int. J. Agri. Biol. 12:241-246.

Griffing, B. 1956. Concept of general and specific combining ability in relation to diallel crossing system. Aust. J. Biol. Sci. 9: 463-493.

Groos, C., N.Robert, E.Bervas and G.Charmet. 2003. Genetic analysis of grain protein-content, grain yield and thousandkernel weight in bread wheat. Theor. Appl. Genet. 106:10321040.

Hayman, B.I. 1954. The theory and analysis of diallel crosses. Genetics 39:789-809.

Hussain, F., R.A.Sial and M.Ashraf. 2008. Genetic studies for yield and yield related traits in wheat under leaf rust attack. Int. J. Agri. Biol. 10:531-535.

Hussain, T., W.Nazeer, M.Tauseef, J.Farooq, M.Naeem, K.Mahmood, M.Iqbal, A.Hameed, H.M.Nasrullah and S.Freed. 2012. Inheritance of some spike related polygenic traits in spring Wheat (Triticum aestivum L). Afr. J. Agric. Res. 7: 1381-1387.

Inamullah, H.Ahmad, F.Mohammad, Siaj-Ud-Din, G.Hassan and R.Gul. 2006. Diallel analysis of the inheritance pattern of agronomic traits of bread wheat. Pak. J. Bot. 38:1169-1175.

Kashif, M. and I.Khaliq. 2003. Mechanism of genetic control of some quantitative traits in bread wheat. Pak. J. Boil. Sci. 6: 1586-1590.

Kashif, M. and I.Khaliq. 2004. Heritability, correlation and path coefficient analysis for some metric traits in wheat. Int. J. Agri. Biol. 6:138-142. 
Khaliq, I., N.Parveen and M.S.Chowdhry. 2004. Correlation and path coefficient analysis in bread wheat. Int. J. Agri. Biol. 6:633-635.

Khan, A.J., F.Azam and A.Ali. 2010. Relationship of morphological traits and grain yield in recombinant inbread wheat lines grown under drought conditions. Pak. J. Bot .42:259-267.

Khan, M.H. and A.N.Dar. 2010. Correlation and path coefficient analysis of some quantitative traits in wheat. Afr. Crop Sci. J. 18:9-14.

Khokhar, M.I., M.Hussain, M.Zulkiffal, N.Ahmad and W.Sabar. 2010. Correlation and path analysis for yield and yield contributing characters in wheat (Triticum aestivum L.). Afr. J. Plant Sci. 4:464-466.

Liu, X.Y. and Y.Z.Wei. 2006. Genetic study on winter wheat yield characters. Chin. J. App. Environ. Biol. 12:1-4.

Lu, B., B.Ding, X.T.Lu, Z.W.Yu, G.C.Zhao and F.S.Wan. 2010. Arrangement planning of Chinese wheat ascendant regions. Chinese J. Agric. Resouces and Regional Planning 31:6-12.

Mahter, K. and J.L.Jinks. 1982. Biometrical Genetics. 3rd Edition. Chapman and Hall, London. UK.

Mckendry, A.L., P.B.E.Mcvetty and L.E.Evans.1998. Inheritance of grain protein concentration, grain yield, and related traits in spring wheat (Tnticum aestivum L.). Genome 30:857-864.

Munir, M., M.A.Chowdhry and T.A.Malik. 2007. Correlation studies among yield and its components in bread wheat under drought conditions. Int .J. Agri. Biol. 9:287-290.

Nazeer, W., Z.Ali, A.Ali and T.Hussain. 2010. Genetic behaviour for some polygenic yield contributing traits in wheat (Tnticum aestivum L.). J. Agric. Res. 48:267-277.

Nazeer, W., J.Farooq, M.Tauseef, S.Ahmed, M.A.Khan, K.Mahmood, A.Hussain, M.Iqbal and H.M.Nasrullah. 2011. Diallel analysis to study the genetic makeup of spike and yield contributing traits in wheat (Triticum aestivum L.). Afr. J. Biotechnol. 10: 13735-13743.

Novoselovic, D., M.Baric, G.Drezner, J.Gunjaca and A.Lalic. 2004. Quantitative inheritance of some wheat plant traits. Genet. Mole. Biol. 27:92-98.
Ojaghi, J. and E.Akhundova. 2010. Genetic analysis for yield and its components in doubled haploid wheat. Afr. J. Agric. Res. 5:306-315.

Paroda, R.S. and A.B.Joshi. 1970. correlations, path-coefficients and the implication of discriminate function for selection in wheat (Triticum aestivum L.). Heredity 25:383-392.

Riaz, R. and M.A.Chowdhry. 2003. Genetic analysis of some economic traits of wheat under drought condition. Asian. J. Plant Sci. 2:790-796.

Saleem, M., M.A.Chowdhry, M.Kashif and M.Khaliq. 2005. Inheritance pattern of plant height, grain yield and some leaf characteristics of spring wheat. Int. J. Agri. Biol. 7:10151018.

Samiullah, A.S.Khan, A.Raza and S.Sadique. 2010. Gene action analysis of yield and yield related traits in spring wheat (Triticum aestivum). Int. J. Agri. Biol. 12:125-128.

SAS. 2002-2003. User's guide; Statistics, version 9.1. SAS Institute Inc. Cary, NC, USA.

Shen, H.Y. 2012. Analysis and prospect of China wheat market in 2011. Food and Oil 3:39-42.

Singh, R.B. and G.S.Sharma.1976. Induced polygenic variations in relation to gene action for yield and yield components in spring wheat. Can. J. Genet. Cytol. 18:217-223.

Tang, Q.Y. and M.G.Feng. 2002. Practical statistics and data processing system. Beijing: Science Press.

Tian, J.C., Z.Y.Deng, R.B.Hu and Y.X.Wang. 2012. Yield components of super wheat cultivars with different types and the path coefficient analysis on grain yield. Acta Agron. Sin. 32:1699-1705.

Wang, C.L., H.T.Gao, S.Z.Wang, G.H.Duan, S.H.Wu, X.P.Zhang and S.Z.Lu. 2003. Genetic analysis of quality and yield characters in winter wheat. J. Triticeae Crops 23:26-28.

Xiao, S.H. 2006. Trend of wheat breeding and food security in China. Sci. Tech. Rev. 24:5-7.

Yang, S.Q. and Y.P.Cao. 2005. Genetic studies on three grain weights character in winter wheat. J. Henan Institute Sci. Tech. 33: 4-6.

Zhang, L.H. and M.F.Xu. 1997. An analysis of genetic effects on harvest index and several other agronomic characteristics of wheat. Acta Agri. Nucle. Sin. 11:135-140. 